Chang, P. (2016). Wartime interpreting during the Sino-Dutch War (1661-1662). Linguistica Antverpiensia, New Series: Themes in Translation Studies, 15, 51-71.

\title{
Wartime interpreting during the Sino-Dutch War (1661-1662)
}

\section{Pin-ling Chang}

Chung Yuan Christian University, Taiwan

pinling.chang@cycu.edu.tw

While wartime interpreting has become a research focus in very recent years, little research has explored on-the-battleground interpreting for warring sides in pre-modern times. By examining the Dutch East India Company (VOC) archival resources and other relevant historical documents, this study discusses interpreting practices during the SinoDutch War (1661-1662) in seventeenth-century colonial Taiwan, with a focus on interpreters' backgrounds, functions and status, issues of loyalty and trust, and interpreters and translation as a tool of manipulation and power struggles. The overview of the interpreters and the interpreting practices in pre-modern wartime viewed against our present experience shows both differences and similarities in wartime interpreting between the past and the present; it also indicates that although the importance of interpreters has been increasingly recognized, they have remained a symbol of both relief and distrust since ancient times.

\section{Introduction}

Wartime interpreting has become one focus of attention in translation studies in recent years (e.g., Baker, 2010; Dragovic-Drouet, 2007; Inghilleri, 2009; Palmer, 2007; Rafael, 2010; Stahuljak, 2010a, 2010b) largely because of the occurrence of some large-scale, protracted international or inter-ethnic conflicts in modern times and therefore the availability of adequate and varied types of data, such as media reports, war archives in written and/or audiovisual form, interviews with the parties concerned and memoirs or books. In contrast, even though the earliest proof of the use of military interpreters can be traced back to the third millennium BC around ancient Egypt (Kurz, 1985), the records of interpreting practice in the conflicts that took place in pre-modern times are relatively meagre, fragmented, peripheral or indirect (e.g., Alonso Araguás \& Baigorri Jalón, 2004; Wong, 2007), while in some other cases, even fictional plots are used as the fundamental material for research discussion (e.g., Beebee, 2010; Cronin, 2006, Chapter 3; Maier, 2007). This may be caused by the vicissitudes of war, the evanescent nature of spoken words (Bowen, Bowen, Kaufmann, \& Kurz, 1995, p. 245) and/or the trivialization of or contempt for interpreters (e.g., Li, 2002, pp. 1-5; 
Roditi, 1982, p. 6). Yet, even nowadays with the advancement of technologies and the elevated status or visibility of interpreters, only very few previous studies provide direct observation or experience of wartime interpreting practice, and they mainly concern interpreting for the media or in asylum, court and refugee contexts (Dragovic-Drouet, 2007; Jacquemet, 2010; Stahuljak, 2010a).

To compensate for not only the scarcity of wartime interpreting data in pre-modern times but also the dearth of research into on-thebattleground interpreting practice for warring sides, this present study investigates the interpreting practice during the Sino-Dutch War in seventeenth-century colonial Taiwan. This protracted multi-ethnic war between Europeans and Chinese, which broke out on 30 April 1661 and ended in February of 1662, involved not only fierce battles but also many interpreter-mediated negotiations through letters and meetings, most of which were carefully documented in the archives of the Dutch East India Company (Vereenigde Oost-Indische Compagnie, VOC). ${ }^{1}$ The most detailed documents concerning the Sino-Dutch War include, among others, Dagregisters van het kasteel Zeelandia (the day-to-day official reports of Fort Zeelandia, the headquarters of the Dutch Taiwan administration), the journal of ad hoc Dutch interpreter Philip Meij, ${ }^{2}$ and the memoir of last Dutch Taiwan governor Frederic Coyett. In contrast, the Chinese side left only very limited and indirect records relating to interpreting and interpreters during this war. Yet, taken in their totality, the already uncovered historical records of this war finally allow for a detailed discussion and analysis of pre-modern wartime interpreting, particularly in terms of the interpreters' backgrounds, functions, and status, issues of loyalty and trust, and the use of interpreters and translation as a tool of manipulation and power struggles. In addition, by examining and understanding pre-modern wartime interpreting practice against our present experience, it shall be made clear whether any differences lie between the past and the present and, if so, what they might be. This comparison may in turn shed light on the position of interpreters in conflict situations of all times.

\section{The Sino-Dutch War (1661-1662)}

Prior to the Sino-Dutch War, there had been frequent contact and conflicts over the trade between Taiwan and China (e.g., Chiang, 1999/1986, pp. 10-14). At the time, the southeast coastal area of China was controlled by Koxinga (1624-1662), who was also known as Cheng Cheng-kung, a loyalist of Ming China (the Ming dynasty of imperial China, 1368-1644). After the Manchurians established Qing China (the last dynasty of imperial China) in the Chinese mainland in 1644, Koxinga waged war against Qing China in a vain attempt to restore Ming China. Having suffered heavy defeats in battles against Qing China, Koxinga 
decided to retreat to Taiwan on the advice of Chinese interpreter Pinqua, who defected from the Dutch Taiwan colonial administration and suggested making Taiwan a stronghold for Koxinga to contend against Qing China (Jiang, 1958/1704, pp. 190-191; see also Section 4.1). On 30 April 1661, Koxinga started his attack on Taiwan. Within one week of the war, he took complete control of Fort Provintia, one of the two main Dutch fortresses where the Dutch Taiwan colonial administration was based, but his final victory did not come until he seized the other fortress, Fort Zeelandia, on 1 February 1662. The protracted war caused both warring sides heavy losses and pain. The long siege of Fort Zeelandia brought the Dutch both distress and hope: on the one hand, due to enemy shelling and a lack of resources, those inside the fort suffered deteriorating health conditions, both physically and psychologically. On the other hand, they pinned their hopes on the arrival of reinforcements from Batavia (known as today's Jakarta, where the VOC's Asian headquarters were based) to turn the war. The Chinese side was suffering, too: more and more Chinese soldiers were dying from hunger or failure to acclimatize, with some native communities rising against Koxinga (see also Andrade, 2008 for the detail of the Sino-Dutch War). The weakening of the Chinese army and the stubborn resistance from Fort Zeelandia caused Koxinga to resort to negotiation instead of force, which is why interpreters played an important role during the war. Note that the wartime interpreting practices discussed in this study are limited to those taking place on the battlefield in and around the two aforementioned Dutch fortresses.

\section{Interpreting activity in Dutch Taiwan}

To better understand why interpreters played an important role in the Sino-Dutch War, an overview of the interpreting activity in Dutch Taiwan is required. Prior to the Dutch arrival in the 1620s, Taiwan had been terra nullius (no man's land) lying off the southeast coast of imperial China, mainly inhabited by mutually exclusive and incomprehensible Formosan ${ }^{3}$ tribes and some Chinese settlers; it was frequently visited by peoples from neighbouring countries, such as Japan. To conquer and colonize this ethnically and linguistically diverse island, ${ }^{4}$ the VOC resorted to force and enlisted the help of interpreters, which was a regular pattern of European colonization at the time (Bastin, 2009, p. 489; Lefevere et al., 1995, pp. 148-149). In some other European colonies, such as those in Latin America, the first generation of interpreters were mostly captive natives taught to speak Spanish, with a few Spaniards who had lived there since early expeditions having become interpreters either voluntarily or involuntarily (Bastin, 2009, pp. 486-487). In contrast, from the beginning of the Dutch conquest of Taiwan, some Chinese who had settled on the island and could speak some Formosan languages (Blusse, Everts, \& 
Frech, 1999, p. 1, p. 21) were hired either by the Dutch or by Formosan communities to facilitate negotiations ${ }^{5}$ (Campbell, 1903, p. 127), with a very few captive foreigners, such as a Macanese named Salvador Díaz, being forced to provide interpreting services for the first couple of years (Borao Mateo, 2009, p. 18, p. 44). The heteronomous system of interpreting ${ }^{6}$ was increasingly used in Dutch Taiwan as more and more Formosans were taught to speak the Dutch language in the schools built for evangelization purposes (Campbell, 1903, p. 153, p. 242; Chiang, 2003/1996, p. 449). Meanwhile, the autonomous system of interpreting was also widely used during the Dutch colonization of Taiwan. A few European interpreters were called to Taiwan, such as François Caron (1600-1673), who was a French Huguenot refugee turned Japanese interpreter and who later became one of the Dutch Taiwan governors (Cheng, 2000, pp. xxix-xxx), while many more Europeans dispatched to Taiwan by the VOC were requested or encouraged to learn local languages for administrative, missionary or military purposes (Campbell, 1903, pp. 201-206; Chiang, 2003/1996, pp. 260-261). Some of them were promoted to the status of professional interpreters (e.g., Chiu, 2008, p. 121, p. 268), whereas others provided interpreting services on an ad hoc basis (e.g., Campbell, 1903, p. 203; Chiang, 2003/1996, p. 337).

Both European and local interpreters played an indispensable role in the Dutch conquest, evangelization and management of Taiwan, just as their counterparts in European colonies in Latin America had done (Lefevere et al., 1995, pp. 148-149). Ad hoc interpreters often held regular jobs as clergymen, schoolmasters, soldiers or tribal chiefs (e.g., Campbell, 1903, pp. 540-541; Chiang, 2002/1995, p. 248, p. 252, p. 265), while official interpreters might serve as messengers, envoys or deputies (e.g., Campbell, 1903, p. 169; Chiang, 1999/1986, pp. 416-421) or be appointed as local officials or headmen of Chinese or Formosan communities in charge of tax, trade, or labour affairs (e.g., Blusse, Everts, Milde, \& Ts'ao, 2000, p. 231; Borao Mateo, 2009, p. 168 ; Chiu, 2008, p. 167). Generally, interpreters under Dutch rule enjoyed high status and authority, yet civil resentment or revolt against corrupt or bullying interpreters, whether European or local, was not uncommon (e.g., Blusse \& Everts, 2006, p. 192; Blusse \& Everts, 2010, p. 24; Chiang, 2003/1996, pp. 284-287). What is particularly worth mentioning is that the resistance of local interpreters to the Dutch authorities was not as passive or powerless as what appeared to be the case in some other European colonies, where native interpreters had little choice but to serve as an instrument for colonizing their own people due to unequal power relationships between the colonizer and the colonized (Lefevere et al., 1995, p. 148). Instead, it is often found that the Dutch authorities made concessions or showed leniency to the resistance from local interpreters. In one case, when two Formosan interpreters, Waddij and Balou, stated that they would rather die than accompany the Dutch military to a gold mine site, the Dutch did nothing but let them leave peacefully for fear that 
displeased local interpreters might stop working for them or even instigate civil disturbance (Chiang, 2002/1995, pp. 123-124). In another case, ad hoc Chinese interpreter Hensay was only fined and exiled for being one of the rebel leaders in the Guo Huaiyi Rebellion in 1652, whereas thousands of Chinese farmers rose in revolt to meet their death during that 12-day rebellion (Blusse et al., 2000, pp. 173-174; Chiang, 2003/1996, pp. 285-286). It seems that the use of interpreters had become a necessary evil for the Dutch to colonize Taiwan, yet it was also because of the Dutch reliance on interpreters that Taiwan was lost to Koxinga (see also Section 4.1).

\section{Interpreting activity during the Sino-Dutch War}

The multi-ethnic nature and the long duration of the Sino-Dutch War made interpreters indispensable in bilateral negotiations. The evanescence of spoken words and the vicissitudes of war might have left the later generations only a glimpse of interpreting practices during the war, yet the VOC archival resources have allowed for a clear picture to be formed of such wartime interpreting activity. In the following sections, the discussion and analysis of the interpreting activity during the Sino-Dutch War will focus on the makeup, function and status of interpreters, issues of loyalty and trust, and interpreters and translation as a tool of manipulation and power struggles.

\subsection{Interpreters and interpreting practice}

Both professional and ad hoc interpreters from diverse ethnic and social backgrounds were involved in the Sino-Dutch War. As mentioned in section 3, the great ethnic and linguistic diversity of Taiwan prompted the VOC to enlist the help of interpreters with the colonization of Taiwan for administrative, missionary or military purposes (see also Chang, 2014, pp. 137-142). When the Sino-Dutch War broke out, some professional interpreters who were on or near the battlefield continued to provide interpreting services for either warring side; these included Chinese interpreters Ouhinko, Maiko, Tjoncko, Pinqua, and Maurits (Blusse et al., 2000, p. 357, p. 360, pp. 397-398; Meij, 2003/1662, pp. r16-18). Yet, due to the large scale and long length of the war, many more ad hoc interpreters were involved in the war, such as VOC assistant Willem Pedel, son of a Dutch military commander (Blusse et al., 2000, p. 362), and VOC secretary Paulus Ossewayer (Blusse et al., 2000, pp. 400-401; Meij, 2003/1662, p. r37), with some other unnamed slaves, messengers or soldiers making a cameo appearance (Blusse et al., 2000, p. 441; Meij, $2003 / 1662$, p. r4, p. r57). Yet others were captured and forced to work for 
the opposing side, such as VOC land surveyor Philip Meij (Meij, 2003/1662).

Of all the interpreters involved in the war, Chinese interpreter Pinqua, also known as He Bin in Chinese, might have been the most active and high-profile. Originally a VOC company interpreter and wealthy Chinese headman, Pinqua had been heavily relied on by the Dutch authorities, particularly in terms of negotiation with Koxinga over the trade between China and Taiwan. In the 1650s, Koxinga, who controlled the southeast coastal area of China, imposed a trade embargo on Taiwan in retaliation for the VOC's interference in his trade with the other Asian countries. Pinqua went to China, on behalf of the VOC, successfully persuaded Koxinga to reopen the trade with Taiwan (Blusse et al., 2000, pp. 157-163, pp. 199-201). Pleased with Pinqua's negotiation performance, the Dutch were oblivious to his collusion with Koxinga that later caused the VOC heavy financial losses (Campbell, 1903, p. 390). When the exposure of his unjust tax collection cost him his posts and fortune and prevented him from living luxuriously, Pinqua fled to China and instigated Koxinga to take over Taiwan as a stronghold where Koxinga and his Ming China army could build up their strength and contend against Qing China (Andrade, 2011, pp. 100-107; Jiang, 1958/1704, pp. 190-191). During the Sino-Dutch War, in addition to interpreting Koxinga's meeting with Dutch representatives (Meij, 2003/1662, pp. r16-18), Pinqua also served as Koxinga's envoy to call for the surrender of Fort Zeelandia (Blusse et al., 2000, p. 377) or even 'spontaneously' acted as Koxinga's agent to manipulate Dutch captives (e.g., Andrade, 2011, p. 138; Blusse et al., 2000, p. 358, pp. 521-522) and to induce Dutch personnel to defect to the Chinese side (Blusse et al., 2000 , p. 379). That wartime interpreters engage in tasks irrelevant to interpreting or translation still remains common in modern times. For instance, the Japanese-American interpreters hired and trained by the U.S. military during the Second World War were assigned the tasks of interrogating Japanese war captives, persuading Japanese to surrender, and helping with propaganda activities (Takeda, 2009, p. 52). In another case, local interpreters hired by Western media in Iraq during the U.S.-led coalition force invasion of Iraq in 2003 were expected to perform various duties, such as selecting local interviewees and making security assessments (Palmer, 2007, p. 19).

During the Sino-Dutch War, Dutch land surveyor Philip Meij might have been the most prominent ad hoc interpreter. He had lived in Taiwan for 19 years and was 40 years old when Koxinga attacked the fort and town of Provintia (Chiang, 2003/1662, p. 19). Within one week of the war, Meij went to Koxinga's camp on behalf of the Dutch side to negotiate the terms of Fort Provintia's surrender (Meij, 2003/1662, pp. r16-19). All the Dutch captives at Fort Provintia were then displaced, except for the landdrost (sheriff) and some specialists, including Meij, who were ordered to stay at Koxinga's service (Meij, 2003/1662, p. r31). 
In addition to carrying out land surveying (Meij, 2003/1662, pp. r32-33), Meij was frequently summoned by Koxinga to translate or interpret official letters from or into the Dutch language (Meij, 2003/1662, p. r50, p. r53, p. r57, p. r62) or to travel between both warring sides for negotiation over the final surrender terms (Meij, 2003/1662, pp. r61-62).

While a lack of interpreters during initial inter- or multi-ethnic encounters in colonial contexts often resulted in locals being captured and trained to speak the colonizer's language (e.g., Bastin, 2009, pp. 486-487; Bowen et al., 1995, pp. 258-259), Koxinga's use of captives as interpreters during the Sino-Dutch War was not for the same reason. There was no lack of Chinese or Formosan interpreters at Koxinga's camp as many of them had defected to the Chinese side prior to or at the beginning of the war (e.g., Andrade, 2011, pp. 100-107; Blusse et al., 2000, p. 374; Meij, 2003/1662, p. r21).

It is very likely that Dutch land surveyor Philip Meij was thrust into the role of the interpreter because of his high status on the Dutch side, which might have been influential in shaking the Dutch military's confidence and ending the war earlier. More specifically, near the end of the war, in one letter to the Dutch military personnel that appealed to their good sense for surrender, Koxinga specified that the letter was written in Dutch by "Philip" (Blusse et al., 2000, p. 654). It is likely that Koxinga might have thought that specifying Meij as the translator of the letter could help increase the authority and authenticity of the letter and/or that using the first name of Meij showed a sign of friendliness between Meij and himself, which might soften the Dutch resistance against him.

How interpreters or translators are selected or deployed has been much discussed in modern wartime interpreting studies. In a study of the role of interpreters in the international peace operations in BosniaHerzegovina, the British military language trainer Gregory Cook expresses the view that the concern over the 'baggage' carried by local interpreters may influence their use. That 'baggage' may contain their values, contacts or hidden motives associated with personal conflicts, family matters, and so on in the complex multi-ethnic and historical context, and such baggage may undermine the neutrality of interpreters and possibly the progress of military operations (Kelly \& Baker, 2013, pp. 144-145).

However, in another study of local interpreters or translators working for Western media in Iraq since the U.S.-led coalition force invasion of Iraq in 2003, the 'baggage', or the pasts of interpreters, is viewed by French journalists as "a useful way of opening doors in Iraqi society" (Palmer, 2007, p. 18). As indicated, whether an interpreter's 'baggage' is considered negative or positive during wartime may be associated with the nature of war and the purpose of interpreting tasks. In the case of Dutch captive-interpreter Philip Meij, his close bond with the Dutch authorities and his language ability prompted Koxinga to rely on him in bilateral negotiations, but it was also for the same reasons that 
Koxinga remained mistrustful of his renditions. On the other hand, for Meij himself, his 'baggage' was both the source of agony and the key to survival. Thus, arguably, interpreters' baggage might be both advantageous and disadvantageous to the warring sides and to interpreters themselves in pre-modern warfare.

\subsection{Status of interpreters}

While researchers may investigate the status of interpreters in ancient times by resorting to the iconography of interpreters and their monarchs (e.g., Alonso Araguás \& Baigorri Jalón, 2004), the detailed VOC archival resources provide more direct and definite evidence of the status of interpreters in the seventeenth century. Generally, during the Sino-Dutch War, interpreters on the Dutch side enjoyed higher status than their counterparts on the Chinese side, whereas European interpreters tended to receive better treatment than their non-European counterparts when both worked for the Chinese side.

First of all, it is found that interpreters' opinions about the war developments were often sought or respected on the Dutch side. For instance, ad hoc Dutch interpreter Meij's proposal for the early surrender of Fort Provintia in order to avoid unnecessary casualties was immediately approved of by the Dutch authorities (Meij, 2003/1662, pp. r11-12). Moreover, the Dutch tended to refrain from mistreating their interpreters. For example, to prevent ad hoc Dutch interpreter Paulus Ossewayer from spreading the news of Koxinga's kindness towards Dutch captives (immediately after the surrender of Fort Provintia), the Dutch authorities at Fort Zeelandia gave him only a verbal warning and kept him in a room for a few hours (Blusse et al., 2000, p. 374). A second example is that of the Dutch authorities threatening Chinese interpreter Kejangh with serious punishment if he gave an unfaithful rendition of a Chinese captive's confession. When Kejangh failed to properly understand the captive's northern Chinese dialect, he did not receive any punishment as threatened (Blusse et al., 2000, p. 396). In contrast, non-European interpreters on the Chinese side often suffered worse treatment than their counterparts on either side. For instance, when Dutch interpreter Paulus Ossewayer and Chinese interpreters Tjoncko and Ouhinko went together to deliver a letter to Fort Zeelandia by order of Koxinga, Ossewayer was on horseback while the two Chinese interpreters were on foot (Blusse et al., 2000, p. 397). Yet another instance is that, although Chinese interpreter Pinqua played a significant role in facilitating Koxinga's attack on Taiwan, he was held in low esteem on the Chinese side. More precisely, Pinqua was widely blamed for deceiving Koxinga into believing it would be easy to seize Taiwan (Meij, 
2003/1662, p. r39) and was even kept in captivity by Koxinga for some time during the war as punishment (Blusse et al., 2000, p. 509, p. 530).

Why Pinqua ended up being despised by his Chinese compatriots might be partly because he had been notorious for his craftiness and corruption as a VOC company interpreter (Andrade, 2007, pp. 10-17) and partly because his change of allegiance was motivated by self-interest rather than by patriotism ${ }^{7}$ (Andrade, 2007, pp. 22-23; Chang, 2014, pp. 145-148). Furthermore, all the Chinese interpreters who defected to the Chinese side, such as Pinqua, had served the VOC and lived comfortably in Taiwan for years. They were therefore heteronomous to Koxinga. As the use of the heteronomous strategy often comes with "the fear of being misled either by the native interpreter or by the non-native interpreter going native" (Cronin, 2002, p. 392), it is unsurprising that Pinqua as a crafty heteronomous interpreter was no more trustworthy than his European counterparts to Koxinga.

In contrast with Chinese interpreter Pinqua, ad hoc Dutch interpreter Meij was held in high esteem by both sides. The Dutch side had a high opinion of Meij as he did not defect to Koxinga or take advantage of his interpreter's position out of self-interest. Instead, Meij tried to bargain for more food or more reasonable treatment for Dutch captives (e.g., Meij, 2003/1662, pp. r34-35, pp. r40-41) and risked his life providing intelligence for the Dutch side (Meij, 2003/1662, pp. r3940, p. r59). Meanwhile, although Koxinga remained suspicious of Meij's rendition, he still relied most on Meij for bilateral negotiations during the war (e.g., Meij, 2003/1662, p. r57, pp. r61-62) and consulted him about the situation of the Netherlands and the VOC's trade affairs (Meij, 2003/1662, pp. r55-57). Koxinga's trust in Meij was most obvious when he believed Meij dared not betray him and thus rejected a German defector's proposal to put Meij to death (Meij, 2003/1662, p. r49). Meij also won support from the other Chinese officials. For example, at the end of the war, when Meij was made an envoy for bilateral negotiations over the terms of the Dutch surrender and found himself faced with extremely furious Koxinga, two high-ranking Chinese officials stood by Meij and helped ease the tension (Meij, 2003/1662, pp. r61-62).

Based on the above discussion, it seems that when wartime interpreters were heteronomous, they might be more likely to be recognized or trusted for their character traits than for their language ability. However, a review of the attitude of the VOC and of Koxinga towards interpreting and interpreters prior to the Sino-Dutch War may help better explain why interpreters during the war tended to receive less respect and worse treatment from the Chinese than from the Dutch. As mentioned in section 3, the Dutch authorities had been keenly aware of the importance of competent interpreters so they financially and/or politically rewarded interpreters for helping manage Taiwan and showed tolerance and leniency towards the inadequacies, disobedience or wrongdoing of interpreters (Blusse et al., 2000, pp. 173-174; Campbell, 
1903, p. 41; Chiang, 2002/1995, pp. 123-124; Chiang, 2003/1996, pp. 285-286). It is then unsurprising that the Dutch continued their positive attitude towards interpreters during wartime. Also, during the war, the Dutch Taiwan colonial administration remained under siege for months with insufficient manpower and resources; they could hardly afford to lose any interpreter, professional or ad hoc.

In contrast, since ancient times interpreters had been generally belittled and disrespected in Chinese society (Li, 2002, pp. 1-5) as the ethnocentric Han Chinese people (the main ethnic group of ancient China) considered themselves to be better than Others and disdained the languages and cultures of those they considered inferior to them, which caused only a few Han Chinese people to be bilingual translators in ancient times (Hung, 2005). Even until the late Qing China period (around the latter half of the nineteenth century), the imperial language or translation schools mainly attracted low-quality students, who came only for official subsidies (Hsü, 1995, p. 271), while translation was still seen as "a means to know the strengths of the barbarians to control the barbarians", with translators and interpreters often labelled as traitors or evil-doers due to their connection with foreigners (Wong, 2007, p. 42, p. 54).

It is clear that the deep-seated Chinese sense of cultural superiority had translated into both a lack of competent Chinese interpreters and the low status of interpreters, which explains why the Chinese side during the Sino-Dutch War could hardly find autonomous interpreters and why interpreters were held in low esteem on the Chinese side.

\subsection{Issues of loyalty and trust}

The issue of interpreters' loyalty was rather complicated during the SinoDutch War due to the complex makeup of interpreters and the developments of war. While wars are widely considered to be of ethnocentric nature (e.g., Bartov, 1992), the Sino-Dutch War featured ethnic mixing and cultural hybridity. The forces of the Dutch side were mainly made up of European mercenaries, and their interpreters were from European, Chinese or Formosan backgrounds. Whereas Koxinga led an army made up of Chinese soldiers, his interpreters were all heteronomous from the same diverse ethnic backgrounds as those on the Dutch side.

The social solidarity of Dutch Taiwan was actually built and maintained by means of force, religion or reward, with multiple cohabiting ethnicities remaining autonomous and separate. More specifically, mutually exclusive Formosan tribes had no concept of nationhood (Campbell, 1903, pp. 89-90). Even after they were subjected to Dutch rule due to military suppression (e.g., Chiang, 1999/1986, pp. 232-247) and/or evangelization (Campbell, 1903, p. 182), they each still 
remained autonomous with their own tribal identity and language. Meanwhile, most Chinese settlers moved to Taiwan under Dutch rule mainly to escape the political and economic turmoil caused by the Manchu conquest of the Chinese mainland and to pursue a better life promised by the Dutch that needed Chinese recruits to deal with communication with Formosans and/or to help with agriculture and trade in Taiwan (Shepherd, 1993, pp. 83-90). Those Chinese were not nationalist-minded but practical and adaptable.

The Dutch Taiwan colony in the Sino-Dutch War was actually similar to the former Yugoslavia in the 1990s, where "in moments of crisis and state reconfiguration, the concept of hybrid identity readily [broke] down into its constituent identities" (Ballinger, 2004, p. 48). Therefore, when the odds were in favour of the Chinese side in the war, it is not surprising to see the Dutch Taiwan society breaking down easily and its multi-ethnic people switching allegiances. Not only did Chinese and Formosan interpreters change sides (Blusse et al., 2000, pp. 373-374, pp. 397-399, pp. 449-451; Meij, 2003/1662, p. r21); some European soldiers and slaves also defected to the Chinese side and performed ad hoc interpreting tasks. For instance, a black slave was sent to demand in Portuguese that a short note from Fort Zeelandia be translated into Chinese (Blusse et al., 2000, p. 441). On another occasion, the defectors were gathered by order of Koxinga to confirm the appropriateness of ad hoc Dutch interpreter Meij's translation into the Dutch language (Meij, 2003/1662, p. r57).

However, some Dutch interpreters still remained loyal to the VOC during the war. For instance, while Koxinga attempted to bribe and threaten Dutch assistant-interpreter Willem Pedel to help facilitate the Dutch surrender, Pedel stood firm and remained with his Dutch superiors (Blusse et al., 2000, pp. 363-364). Another instance involved Dutch secretary-interpreter Paulus Ossewayer, who refused to be recruited by Chinese interpreter Pinqua, continued his job for his Dutch superiors until beheaded by Koxinga several months before the end of the war (Blusse et al., 2000, p. 677). Some other Chinese and Formosan interpreters also remained with the VOC. For example, Chinese interpreter Maurits refused to take bribes from Koxinga, who asked Maurits to urge his Dutch superiors to surrender Fort Provintia (Blusse et al., 2000, p. 360, p. 489). Hence, while the ethnicity and nationality of modern wartime interpreters may help determine whether or how much they may be trusted (e.g., Kelly \& Baker, 2013; Takeda, 2009), this principle is not applicable to the case of the Sino-Dutch War.

Issues of divided loyalties remain the main concern of the warring sides involved nowadays. In inter-ethnic conflicts, such as those between Americans and Iraqis during the U.S.-led coalition force invasion of Iraq in 2003, Iraqi interpreters hired by Americans are seen as either "faithful to their task by being unfaithful to their origins" or vice versa, which causes them to be doubted by both warring sides (Rafael, 2010, p. 388). 
However, in the Sino-Dutch War, ad hoc Dutch interpreter Philip Meij was loyal to his origin and his interpreting tasks but disloyal to his client (Koxinga). Meij was found to have adequately fulfilled the interpreting and translation tasks assigned by his captor Koxinga (e.g., Meij, 2003/1662, p. r55). There was even one clear piece of evidence that confirms the faithfulness of his rendition.

Specifically, when both warring sides started to negotiate the surrender terms at the end of the war, Koxinga was inappropriately addressed in one Dutch letter delivered by two Dutch representatives. Meij was requested by Koxinga to interpret the letter into Chinese and then translate Koxinga's reply into Dutch. It was clearly stated in Koxinga's reply that his inappropriate title in the Dutch letter was why he had refused to give the Dutch representatives an audience (Meij, 2003/1662, pp. r53-55). Meij might have known the inappropriate title would anger Koxinga, whom he described in his journal as irritable and tyrannical (Meij, 2003/1662, pp. r27-30), but he interpreted the letter as it was. In the meantime, Meij had been always psychologically loyal to the Dutch side. For instance, when the VOC succor-fleet arrived off the shore of Taiwan around mid August of 1661 (Coyett, 1975/1675, pp. 72-73), Meij readied himself for the ultimate fight against Koxinga by gathering whatever weapons he could obtain and by secretly sending a drummer to provide military intelligence for the Dutch authorities (Meij, 2003/1662, pp. r39-40). In Meij's case, he never pledged allegiance to Koxinga but simply exchanged his interpreting services for his survival. Arguably, such cases of divided loyalities may be rarely seen nowadays, when interpreters are generally hired on a voluntary basis.

Meanwhile, it is also found during the Sino-Dutch War that the interpreters who worked for Koxinga on a voluntary basis might not maintain the same degree of loyalty all the time. Some might show sympathy for Dutch captives (e.g., Meij, 2003/1662, p. r45) or provide intelligence on impulse for the Dutch authorities even though they had no intention of switching their allegiance back to the Dutch side (e.g., Blusse et al., 2000, pp. 373-374). In one case, Chinese interpreter Maiko tipped off ad hoc Dutch interpreter Meij that he should avoid danger by keeping a low profile as Koxinga meant to have all the Dutch captives killed (Meij, 2003/1662, p. r45). In another riskier case, when a Belgian defector reported to Koxinga that Meij had provided intelligence for Fort Zeelandia, the defector's words were unfaithfully rendered by an unnamed Chinese interpreter, who later even deterred the defector and his companion with death threats from mentioning Meij again and also advised Meij to remain cautious (Meij, 2003/1662, pp. r47-48). These examples indeed echo Cronin's (2006) viewpoint that "[f]or interpreters in situations of conflict, ... fidelity is a relative rather than an absolute notion" (p. 86).

Also noteworthy is that both warring sides adopted some measures to limit the impact of disloyalty and to ensure the faithfulness of 
renditions. Threatening interpreters with severe punishment was one common way. For example, Chinese tenant and interpreter Kejangh in the VOC's service was summoned by the Dutch and threatened with severe punishment if he failed to interpret faithfully the confession of a Chinese captive (Blusse et al., 2000, p. 396). On some other occasions, both sides had their own interpreters join negotiations instead of relying on those provided by the opposing side, and such joint interpreting should have prevented unfaithful rendition (Andrade, 2011, pp. 143-145; Blusse et al., 2000, pp. 362-364).

Meanwhile, interpreting and translation rendition might be subject to censorship. On the Chinese side, translations might be completed jointly by two translators of different ethnic backgrounds or verified by some others who knew both Chinese and Dutch. For example, when a letter from last Dutch Taiwan governor Frederic Coyett to Dutch politician-interpreter Hendrick Noorden was intercepted and sent to Koxinga in late July of 1661, ad hoc Dutch interpreter Meij and another unnamed interpreter were made by order of Koxinga to jointly translate the letter into Chinese (Meij, 2003/1662, p. r50). Moreover, before Meij left Taiwan with the other Dutch captives in early February of 1662, he was ordered by Koxinga to translate collaboratively with Chinese interpreter Pinqua the inventory of what was stored in the Dutch warehouses (Meij, 2003/1662, p. r62). Another example occurred a few days before the Dutch surrender, when Meij was requested to place his translation of two Chinese letters on the ground in front of Koxinga so that all of those defecting to Koxinga could read the translation aloud in unison and confirm its appropriateness ( Meij, 2003/1662, p. r57).

Checking out the rendition of distrustful interpreters has continued to be applied in modern wartime in different ways. For instance, during the Iraqi war in 2003, Western media journalists might paraphrase the same questions several times to ensure the consistency of the obtained information, check out the information with other sources, or consult other journalists about the reputation of the interpreter concerned (Palmer, 2007, p. 21).

\subsection{Interpreters/translation as a tool of manipulation and power struggles}

During this war, some interpreters might have taken advantage of their position and manipulated others out of personal interest. For instance, Chinese interpreter Pinqua fabricated a letter in the name of Koxinga, demanding the immediate presence of his former Dutch superiors, who reluctantly rushed to Koxinga's tent, only to find there was no such order (Meij, 2003/1662, p. r24). It is uncertain whether Pinqua meant to fool these Dutchmen or did so by order of Koxinga; if the former was the case, Pinqua had succeeded at least in increasing distrust between both sides 
and in demonstrating his power over his former VOC superiors. In this sense, translation is not an instrument in the service of imperial power but "a kind of power productive of other modalities of empowerment that comes with crossing and double-crossing differences, linguistic as well as social" (Rafael, 2010, p. 387).

Meanwhile, interpreters were also found to be objects of manipulation. For instance, ad hoc Dutch interpreter Willem Pedel and two Dutch representatives together witnessed fully armed regiments marching by, one after another, during their long wait for Koxinga to give them an audience, but they later found some faces reappearing in different regiments and sensed that the march was meant to frighten them into believing how powerful the Chinese army was (Coyett, 1975/1675, pp. 50-52). Similar tricks were played on ad hoc Dutch interpreter Philip Meij during the war; he alone was shown how successfully Koxinga and one Chinese officer shot arrows from a bow on a galloping horse (Meij, 2003/1662, p. r54). Just as Footitt and Kelly (2012) point out, "languages [are] actually embedded within military strategy and operational concerns" (p. 11). This has been true for centuries, because manipulating Dutch interpreters was one of Koxinga's military strategies in this war.

Moreover, interpreting and translation might be used for power struggles between warring sides in pre-modern warfare. After the Dutch lost the first major battle against Koxinga, they responded to Koxinga's previous written threats with a courteous letter in which they claimed the delay of a proper reply had been due to a lack of adequate translators (Blusse et al., 2000, p. 361), which should be only an excuse as this first Dutch formal letter was followed by frequent correspondence between both sides. Then, when the Dutch authorities found three unsealed Chinese letters placed outside Fort Zeelandia in late June of 1661, they responded with a very short note in Dutch stating that they refused to accept letters with neither proper inscription nor Dutch translation. The following day a Chinese official conceded by sending a long Dutch letter imprinted with his own seal (Blusse et al., 2000, pp. 440-441). Even near the end of the war, the Dutch authorities still adhered to this principle when they informed Koxinga of their willingness to surrender by specifying in a letter that Koxinga should have his reply written in Dutch if he would like to start the negotiation over the Dutch surrender terms (Blusse et al., 2000, pp. 651-652). The following day, Koxinga did reply with two letters in Dutch written by ad hoc Dutch interpreter Meij (Blusse et al., 2000, pp. 653-655). However, evidence shows that Koxinga did not follow this principle after the Dutch surrendered. In a letter dated 11 February 1662 from the last Dutch Taiwan governor Frederic Coyett to a member of the Board of Formosa, Coyett mentioned that he could not reply to Koxinga's letter before obtaining its Dutch translation from his VOC clerk (Blusse et al., 2000, p. 682).

It seems that, conceding the final defeat, the Dutch were in no position to demand Dutch translation from Koxinga. Also, the fact that 
the Chinese side refused to provide translation in a foreign language reflects the strong Chinese sense of cultural superiority, as discussed in section 4.2. While to translate or not to translate had become an issue of power struggles in pre-modern warfare, the impact of the use of interpreters on the developments of international or inter-ethnic conflicts is being increasingly acknowledged and studied nowadays. Not only is the employment or training of autonomous interpreters highly preferred in order to address loyalty issues (e.g., Takeda, 2009), but also the ability to interpret intelligence and prevent mistranslation is becoming key to winning a war (Apter, 2006, p. 22).

\section{Concluding remarks}

The multi-ethnic nature and the colonial context of the protracted SinoDutch War made interpreters indispensable during wartime. The role of interpreters in the Sino-Dutch War did not change a great deal compared to that in the Dutch colonial context prior to the war. During the Dutch conquest and colonization of Taiwan, interpreters employed under either heteronomous or autonomous systems were heavily relied on due to the great diversity of ethnicities and languages on the island. In addition to language mediation, they were assigned a wide range of tasks for administrative, missionary or military purposes. Some of them were promoted to professional interpreters or interpreter-officials, while others provided interpreting services on an ad hoc basis. Interpreters under Dutch rule generally enjoyed high status and authority. They might not have been as passive or powerless as their counterparts in some other European colonies. Specifically, they might have shown various degrees of resistance, pushing the limit of tolerance and leniency of the Dutch authorities. They served as an instrument at the service of the colonizer, yet interpreting or translation might be turned into a form of power at their own service. Despite their vulnerability to the power of the Dutch colonizer, they remained autonomous and separate, retaining their own languages and identities. Therefore, some of them could swiftly change sides when Koxinga and his Chinese army invaded Taiwan, while war captives might find themselves thrust into the role of the interpreter owing to their backgrounds.

The overview of the interpreters and the interpreting practices during the Sino-Dutch War in the seventeenth century set against our present experience shows some differences in wartime interpreting between the past and the present. In pre-modern times, when captives were made ad hoc interpreters, their loyalties were divided - being loyal to the tasks but disloyal to their captors. Also noteworthy is that although the Sino-Dutch War is widely regarded as an inter-ethnic war between the Chinese and the Dutch (e.g., Andrade, 2011), ethnicity did not become the most important factor in determining whether or how much 
interpreters might be trusted as usually happens in modern warfare. More specifically, the interpreting practice in the Dutch colonial context, the attitude of those in power towards interpreting, and the complex makeup of interpreters on either warring side prevented the interpreters' identities from being "constructed and enforced by other actors" (Baker, 2010, p. 200 ) in the war and kept their images from being polarized on the basis of ethnicity (e.g., Baker, 2010; Kelly \& Baker, 2013; Rafael, 2010). These interpreters might have had fluid identities and allegiances. Their 'baggage' or pasts might have been both advantageous and disadvantageous to themselves and to their employers or captors. They could be both manipulated and manipulative while turning interpreting and translation into a form of power that helped them achieve their aims or survive the struggle between those in power.

There are also similarities in wartime interpreting between the past and the present. Since ancient times, interpreters have been indispensable in inter- or multi-ethnic conflicts and generally vulnerable to the dominant party. They have functioned variously and engaged in a range of tasks irrelevant to interpreting or translation, such as interrogating war captives and persuading enemies to surrender. Ad hoc interpreters have been recruited under the heteronomous system of interpreting, especially in large-scale and protracted wars. Interpreters' language ability and professionalism have not been the main concern of their employers; it is the issues of loyalty and trust that have continued to trouble both employers and interpreters. These similarities indicate that wartime interpreting practices have not changed a great deal over time, and that although the importance of interpreters has been increasingly recognized, they have remained a symbol of both relief and distrust.

\section{References}

Adelaar, A. (2007). Siraya, Taiwan's oldest written language. In C. Storm \& M. Harrison (Eds.), The margins of becoming: Identity and culture in Taiwan (pp. 19-34). Wiesbaden: Harrassowitz.

Alarcón, N. (1989). Traddutora, traditora: A paradigmatic figure of Chicana feminism. Cultural Critique, 13, 57-87.

Alonso Araguás, I., \& Baigorri Jalón, J. (2004). Iconography of interpreters in the conquest of the Americas. TTR, 17(1), 129-153.

Andrade, T. (2007). Chinese under European rule: The case of Sino-Dutch mediator He Bin. Late Imperial China, 28(1), 1-32.

Andrade, T. (2008). How Taiwan became Chinese: Dutch, Spanish, and Han colonization in the seventeenth century. New York, NY: Columbia University Press.

Andrade, T. (2011). Lost colony: The untold story of China's first great victory over the West. Princeton, NJ: Princeton University Press. 
Apter, E. (2006). The translation zone: A new comparative literature. Princeton, NJ: Princeton University Press.

Aveling, H., \& Yamada, T. S. (2009). Southeast Asian traditions. In M. Baker \& G. Saldanha (Eds.), Routledge encyclopedia of translation studies (2nd ed., pp. 527-533). London: Routledge.

Baker, M. (2010). Interpreters and translators in the war zone: Narrated and narrators. The Translator, 16(2), 197-222.

Ballinger, P. (2004). "Authentic hybrids" in the Balkan borderlands. Current Anthropology, 45(1), 31-60.

Bandia, P. (2009). African tradition. In M. Baker \& G. Saldanha (Eds.), Routledge encyclopedia of translation studies (2nd ed., pp. 313-320). London: Routledge.

Bartov, O. (1992). Hitler's army: Soldiers, Nazis, and war in the Third Reich. New York: Oxford University Press.

Bastin, G. L. (2009). Latin American tradition. In M. Baker \& G. Saldanha (Eds.), Routledge encyclopedia of translation studies (2nd ed., pp. 486-492). London: Routledge.

Beebee, T. O. (2010). Shoot the translator!: The translator as homo sacer in fiction and reality. The Translator, 16(2), 295-313.

Blusse, L., \& Everts, N. (Eds.). (2006). The Formosan encounter. Notes on Formosa's aboriginal society: A selection of documents from Dutch archival sources (Vol. III: 1646-1654). Taipei: Shung Ye Museum of Formosan Aborigines.

Blusse, L., \& Everts, N. (Eds.). (2010). The Formosan encounter. Notes on Formosa's aboriginal society: A selection of documents from Dutch archival sources (Vol. IV: 1655-1668). Taipei: Shung Ye Museum of Formosan Aborigines.

Blusse, L., Everts, N., \& Frech, E. (Eds.). (1999). The Formosan encounter. Notes on Formosa's aboriginal society: A selection of documents from Dutch archival sources (Vol. I: 1623-1635). Taipei: Shung Ye Museum of Formosan Aborigines.

Blusse, L., Everts, N., Milde, W. E., \& Ts'ao, Y. (Eds.). (2000). De dagregisters van het Kasteel Zeelandia, Taiwan, 1629-1662: Deel IV: 1655-1662. The Hague: Instituut voor Nederlandse Geschiedenis.

Borao Mateo, J. E. (2009). The Spanish experience in Taiwan, 1626-1642: The baroque ending of a Renaissance endeavor. Hong Kong: Hong Kong University Press.

Bowen, M., Bowen, D., Kaufmann, F., \& Kurz, I. (1995). Interpreters and the making of history. In J. Delisle \& J. Woodsworth (Eds.), Translators through history (pp. 245-273). Amsterdam: John Benjamins.

Campbell, W. (1903). Formosa under the Dutch, described from contemporary records: With explanatory notes and a bibliography of the island. London: Kegan Paul, Trench, Trubner \& Co.

Chang, P. (2014). The political and diplomatic significance of interpreters/translators in seventeenth-century colonial Taiwan. In F. M. Federici \& D. Tessicini (Eds.), Translators, interpreters, and cultural negotiators: Mediating and communicating power from the Middle Ages to the modern era (pp. 136-154). Basingstoke: Palgrave Macmillan. 
Chen, B. 陳碧笙. (2000). 鄭成功歷史研究 [Koxinga historical research]. Beijing: Jiuzhou Press.

Cheng, S. 程紹剛. (Ed.). (2000). De VOC en Formosa 1624-1662. Taipei: Linking Publishing.

Chiang, S. 江樹生. (Ed.). (1999/1986). 熱蘭遮城日誌第一冊 (Translated into Chinese. Original De dagregisters van het Kasteel Zeelandia, Taiwan 16291662, Deel I: 1629-1641, 1986) (Shu-sheng Chiang, Trans., Annot. and Ed.). Tainan, Taiwan: Tainan City Government.

Chiang, S. 江樹生. (Ed.). (2002/1995). 熱蘭遮城日誌第二冊 (Translated into Chinese. Original De dagregisters van het Kasteel Zeelandia, Taiwan 16291662, Deel II: 1641-1648, 1995) (Shu-sheng Chiang, Trans., Annot. and Ed.). Tainan, Taiwan: Tainan City Government.

Chiang, S. 江樹生. (Ed.). (2003/1996). 熱蘭遮城日誌第三冊 (Translated into Chinese. Original De dagregisters van het Kasteel Zeelandia, Taiwan 16291662, Deel III: 1648-1655, 1996) (Shu-sheng Chiang, Trans., Annot. and Ed.). Tainan, Taiwan: Tainan City Government.

Chiang, S. 江樹生. (2003/1662). 梅氏日記: 荷蘭土地測量師看鄭成功 [Journal of Philip Meij: A Dutch land surveyor's portrait of Koxinga] (Translated into Chinese. Original Daghregister van Philip Meij, 1662) (Shu-sheng Chiang, Trans., Annot. and Ed.). Taipei: Echo Magazine.

Chiu, H. (2008). The colonial 'civilizing process' in Dutch Formosa 1624-1662. Leiden: Brill.

Coyett, F. (1975/1675). Neglected Formosa: A translation from the Dutch of Frederic Coyett's 't Verwaerloosde Formosa (Translated into English. Original 't Verwaerloosde Formosa, 1675) (Inez de Beauclair, Trans. and Ed.). San Francisco, CA: Chinese Materials Center.

Cronin, M. (2002). The empire talks back: Orality, heteronomy and the cultural turn in interpreting studies. In F. Pöchhacker \& M. Shlesinger (Eds.), The interpreting studies reader (pp. 386-397). London: Routledge.

Cronin, M. (2006). Translation and identity. London: Routledge.

Dragovic-Drouet, M. (2007). The practice of translation and interpreting during the conflicts in former Yugoslavia (1991-1999). In M. Salama-Carr (Ed.), Translating and interpreting conflict (pp. 29-40). Amsterdam: Rodopi.

Footitt, H., \& Kelly, M. (2012). Introduction. In H. Footitt \& M. Kelly (Eds.), Languages at war: Policies and practices of language contacts in conflict (pp. 1-15). Basingstoke: Palgrave Macmillan.

Hsü, I. C. Y. (1995). The rise of modern China (5th ed.). New York: Oxford University Press.

Hung, E. (2005). Cultural borderlands in China's translation history. In E. Hung (Ed.), Translation and cultural change: Studies in history, norms, and image projection (pp. 43-64). Amsterdam: John Benjamins.

Inghilleri, M. (2009). Translators in war zones: Ethics under fire in Iraq. In E. Bielsa \& C. Hughes (Eds.), Globalization, political violence and translation (pp. 207-221). Basingstoke: Palgrave Macmillan. 
Jacquemet, M. (2010). The registration interview: Restricting refugees' narrative69 performance. In M. Baker (Ed.), Critical readings in translation studies (pp. 133-151). London: Routledge.

Jiang, R. 江日昇. (1958/1704). 台灣外記 [A supplemental history of Taiwan]. Taipei: Economic Research Office, Bank of Taiwan.

Kelly, M., \& Baker, C. (2013). Interpreting the peace: Peace operations, conflict and language in Bosnia-Herzegovina. Basingstoke: Palgrave Macmillan.

Kurz, I. (1985). The rock tombs of the princes of Elephantine: Earliest references to interpretation in Pharaonic Egypt. Babel, 31(4), 213-218.

Lefevere, A., Rodriguez, L. A., Ballard, M., Pym, A., Foz, C., Simon, S., de Russel, D. J. M. S., Talbot, G., \& Touitou-Benitah, C. (1995). Translators and the reins of power. In J. Delisle \& J. Woodsworth (Eds.), Translators through history (pp. 131-155). Amsterdam: John Benjamins.

Li, N. 黎難秋. (2002). 中國口譯史 China interpretation history. Qingdao: Qingdao.

Lin, H. 林漢達 \& Cao, Y. 曹余章. (Eds.). (2002). 上下五千年(新版) [Up and down through five thousand years (new edition)]. Shanghai: Juvenile \& Children's Publishing House.

Mackay, G. L. (1895). From far Formosa: The island, its people and missions (4th ed.). New York, NY: Fleming H. Revell.

Maier, C. (2007). The translator's visibility: The rights and responsibilities thereof. In M. Salama-Carr (Ed.), Translating and interpreting conflict (pp. 253-266). Amsterdam: Rodopi.

Meij, P. (2003/1662). Daghregister van Philip Meij. In S. Chiang 江樹生 (Ed.), 梅氏 日記: 荷蘭土地測量所看鄭成功 [Journal of Philip Meij: A Dutch land surveyor's portrait of Koxinga] (pp. rear 1-64). Taipei: Echo Magazine.

Mirandé, A., \& Enríquez, E. (1979). La Chicana: The Mexican American woman. Chicago, IL: University of Chicago Press.

Palmer, J. (2007). Interpreting and translation for Western media in Iraq. In M. Salama-Carr (Ed.), Translating and interpreting conflict (pp. 13-28). Amsterdam: Rodopi.

Rafael, V. (2010). Translation in wartime. In M. Baker (Ed.), Critical readings in translation studies (pp. 383-390). London: Routledge.

Roditi, E. (1982). Interpreting: Its history in a nutshell. Washington, D.C.: Georgetown University, National Resource Center for Translation and Interpretation Outreach Paper.

Shepherd, J. R. (1993). Statecraft and political economy on the Taiwan frontier, 1600-1800. Stanford, CA: Stanford University Press.

Stahuljak, Z. (2010a). War, translation, transnationalism: Interpreters in and of the war (Croatia, 1991-1992). In M. Baker (Ed.), Critical readings in translation studies (pp. 391-414). London: Routledge.

Stahuljak, Z. (2010b). Minor empires: Translation, conflict, and postcolonial critique. The Translator, 16(2), 255-274.

Takeda, K. (2009). War and interpreters. Across Languages and Cultures, 10(1), 4962. 
Wong, L. W. (2007). Translators and interpreters during the Opium War between Britain and China (1839-1842). In M. Salama-Carr (Ed.), Translating and interpreting conflict (pp. 41-57). Amsterdam: Rodopi.

1 The VOC empire used to require its colonies to send back documents and letters, which are now well preserved in the Nationaal Archief of the Netherlands. In recent decades, the VOC archival resources about seventeenth century colonial Taiwan have been gradually uncovered, sorted, and translated from the Old Dutch language into Japanese, English, Mandarin Chinese, etc. In the beginning, relevant publications in Mandarin Chinese were indirectly translated from Japanese or English. Then, a few Taiwanese historians emerged and acquired competence in translating from the Old Dutch into Mandarin Chinese. In this paper, in the event of the unavailability of the VOC archival resources in the original Old Dutch language, I turn to the literature translated directly from the Old Dutch originals or produced by the researchers who directly used the original Old Dutch materials.

2 Interpreters' presence during important cross-cultural encounters naturally makes them serve the testimonial function (Cronin, 2006, p. 81). In this case, the journal of ac hoc Dutch interpreter Philip Meij becomes a very important source of information on pre-modern wartime interpreting practice. The journal has been translated into Mandarin Chinese by eminent researcher Chiang Shu-sheng (Chiang, 2003/1662), with the Old Dutch source text attached to the back of the translation, hence the page numbers of the Dutch original beginning with the letter ' $r$ ' (meaning 'rear').

3 Taiwan island was named Formosa by Portuguese mariners in the early sixteenth century (Mackay, 1895, p. 47), hence the native islanders named Formosans.

4 A least 25 Formosan languages were spoken on the island at the time (Adelaar, 2007, p. 19), and they were not in written form until the Dutch taught Formosans to write in Latin characters (e.g., Campbell, 1903, p. 147). Romanizing local spoken languages for missionary purposes was very common in European colonies in Southeast Asia (Aveling \& Yamada, 2009, p. 531) and Africa (Bandia, 2009, pp. 314-315). Yet, throughout the Dutch Taiwan colonial period, the Formosan languages were never banned but promoted through education and evangelization, and the use of Romanization helped preserve some Formosan cultures and languages (Campbell, 1903, p. 540). This was contrary to what Spanish colonizers did in Latin America, where the native languages were neglected, thus causing the loss of valuable translations and documents (Bastin, 2009, p. 488; Lefevere et al., 1995, p. 149).

5 Before the Dutch arrived in Taiwan, they had had frequent encounters or conflicts with Chinese, Japanese, Spaniards, and Portuguese in Asia (Chiang, 1999/1986, pp. 10-14). 
6 Autonomous and heteronomous systems of interpreting were commonly used in building a colonial empire. The former is defined as "one where colonizers train their own subjects in the language or languages of the colonized", while the latter involves "the recruitment of local interpreters and teaching them the imperial language" (Cronin, 2002, p. 393).

7 It is intriguing to find Pinqua's role redefined more than once by his Chinese compatriots in later times just as the case of Doña Marina, who was a native interpreter that facilitated the Spanish conquest of the Aztec Empire. Marina as an interpreter was not highly approved by her local contemporaries according to the Florentine Codex by Franciscan friar Bernardino de Sahagún (1499-1590) (Bowen et al., 1995, p. 261), portrayed as trecherous in postindependence Mexico (Mirandé \& Enríquez, 1979, p. 24), and now seen as a positive role model for cross-cultural exchange from feminist perspectives (Alarcón, 1989). In a similar vein, Pinqua was described as a double-dealer with insatiable greed by his Chinese contemporaries (Andrade, 2007, p. 14), a person who contributed greatly to the fight against the Dutch by Chinese researchers nowadays (Chen, 2000, p. 101), and "a patriotic man" in a history textbook for young Chinese readers (Lin \& Cao, 2002, p. 1111). It seems that the image of the interpreter may vary with socio-political and cultural contexts. 